\title{
The effects of prescribed fire on soil nematodes in an arid juniper savanna
}

\author{
Walter G. Whitford ${ }^{1}$, Stanislav Pen-Mouratov ${ }^{2}$, Yosef Steinberger ${ }^{2 *}$ \\ ${ }^{1}$ USDA-ARS Jornada Experimental Range, New Mexico State University, Las Cruces, USA \\ ${ }^{2}$ The Mina and Everard Goldman Faculty of Life Sciences, Bar-Ilan University, Ramat-Gan, Israel; \\ *Corresponding Author: yosef.steinberger@biu.ac.il
}

Received 3 January 2014; revised 3 February 2014; accepted 9 February 2014

Copyright (c) 2014 Walter G. Whitford et al. This is an open access article distributed under the Creative Commons Attribution License, which permits unrestricted use, distribution, and reproduction in any medium, provided the original work is properly cited. In accordance of the Creative Commons Attribution License all Copyrights (C) 2014 are reserved for SCIRP and the owner of the intellectual property Walter G. Whitford et al. All Copyright (C) 2014 are guarded by law and by SCIRP as a guardian.

\section{ABSTRACT}

Prescribed fire produced a landscape with two types of severely burned patches: charred shrub patches and charred patches with tree trunks at the center. Soil nematodes were more abundant in burned and unburned juniper (Juniperus monosperma) tree patches than in yucca-shrub patches. There were no differences in nematode abundance between burned and unburned patches during the late spring and summer samples. Nematode abundance was significantly ( $p$ $<0.05$ ) higher in unburned patches than in burned patches in the early spring samples, reflecting large differences in soil moisture between unburned and burned patches. There were no differences in soil nematode abundance between burned and unburned patches at oneyear post-burn and three-year post-burn sites. When all samples were pooled, taxonomic diversity, ecological indices, and abundance of trophic groups (bacteria-feeders, fungi-feeders, and omnivore-predators) were higher in unburned than burned patches. These results suggest that the long-term (up to three years post-burn) effects of fire on soil nematodes are indirect, i.e., by loss of tree canopies, litter accumulation, and shrub foliage, which affects soil temperatures and water redistribution.

\section{KEYWORDS}

Acrobeles; Bacterivore; Fungivore; Omnivore-Predator; Juniperus Monosperma; Soil Moisture; Yucca Baccata

\section{INTRODUCTION}

Most studies on the effects of fire on ecosystems have focused on flora, macrofauna, and atmosphere [1]. Prescribed fires and wildfires can affect the soil subsystem of ecosystems in a number of ways that modify the recovery processes and even the trajectory of recovery from fire. Fire can affect the physical, chemical and biological properties of soil, e.g., aggregate stability, poresize distribution, water repellency, bulk density, decomposer/mineralization food webs, modification of mineralization rates, carbon sequestration, microbial species composition, and nutrient availability [2]. Most studies that consider the effects of fire on soil properties and soil biotic communities have been conducted in forest ecosystems [1,3-6].

In arid and semi-arid ecosystems, fire is frequently used to improve forage production for livestock. Fire studies conducted on arid and semi-arid ecosystems have focused on the control of invasive trees and shrubs in grasslands and savannas utilized for livestock production [7-9]. These studies reported vegetation changes but did not consider the effects of fire on soils or soil organisms. In the arid and semi-arid mountain regions of the American West, junipers (Juniperus spp.) have expanded into the livestock-grazed grasslands and shrub lands, converting these areas into savannas or woodlands $[10,11]$. The increase in juniper density reduces forage production for livestock and wildlife.

Prescribed fire has become one of the most effective management tools for reducing juniper cover and regenerating shrub species that are an important browse for deer and bighorn sheep. Prescribed fire has been used on watersheds on the San Andres Wildlife Refuge in southern New Mexico for more than a decade to improve the habitat for the endangered desert bighorn sheep (Ovis 
canadensis). Prescribed fire in the arid pinyon-juniper savannas on the San Andres Mountain watersheds resulted in an extremely patchy landscape with respect to the intensity of burns of the grassland matrix and patches of shrubs and trees.

Free-living soil nematodes are abundant multicellular animals that participate in fundamental ecological processes in the soil, such as decomposition and nutrient cycling [12-14]. They are sensitive to different kinds of ecosystem disturbances and soil conditions [1,12,15-18].

Previous studies that examined forest-fire impacts on the free-living soil-nematode community reported contradictory conclusions, ranging from confirmation of forest-fire effects on the nematode community $[19,20]$ to refutation of such effects [21]. It was found that, over time, fire does not significantly affect nematode abundance and diversity [22]. However, in the short term after a fire (6 weeks), the total number of bacteria-feeders (Acrobeloides) and omnivore-predators increased while the number of fungi-feeding (Aphelenchoides) nematodes decreased. Root parasites remained unchanged [23].

In arid and semi-arid regions, soil nematode communities vary considerably with seasonal rainfall and soil moisture [24-26]. In arid or semi-arid ecosystems, the effects of fire on soil nematode communities may be directly or indirectly influenced by rainfall and soil moisture $[27,28]$. Moreover, changes in soil structure as a consequence of increasing water evaporation from soil pore caves lead to increases in the predation success of soil free-living nematodes on soil microorganisms [29]. Since there were no studies of the effects of fire on soil decomposition processes, soil nutrient availability, and soil biota in arid juniper savannas, we designed a series of studies to examine the effects of fire on soil processes and soil biota. We hypothesized that the effects of fire on soil nematodes in an arid savanna ecosystem would be very different from those in mesic forests [23] because of seasonal differences in soil moisture. Therefore, we designed studies to examine the seasonal effects of prescribed fire on soil nematode communities in montane juniper (Juniperus monosperma) savannas.

\section{METHODS}

The studies were conducted on adjacent watersheds ( $32.58^{\circ} \mathrm{N}, 106.52^{\circ} \mathrm{W}$ ) in the San Andres Wildlife Refuge, New Mexico, USA: one that was burned in June 2006 and one that was burned in June 2008. The base of the watersheds was at approximately $1970 \mathrm{~m}$ elevation. The grass matrix is dominated by blue grama (Bouteloua) mixed with several other grama grasses, three awns (Aristida spp.), and dropseeds (Sporobolus spp.). Pinyon (Pinus edulis) and juniper (Juniperus monosperma) trees are scattered within the grass matrix but with some dens- er woodland patches in low areas. In addition to the trees, there are shrub patches within the grass matrix. Shrub patches are primarily formed by banana yucca, Yucca baccata, skunk bush (Rhus trilobata), and mes- quite (Prosopis glandulosa). Long-term (90 years) avera- ge rainfall in the area is $344.4 \mathrm{~mm}$, with $57 \%$ of the rainfall occurring during the summer monsoon season (July-September).

The prescribed burns were set at the base of the watershed and the fire moved upslope. Because of variability in fuel and wind, the watersheds did not burn uniformly. The fire followed tortuous paths from the base of the watershed to the unvegetated mountain tops. The burn pattern provided elongated patches of variable width that were burned interspersed with similar elongated patches of unburned savanna. This allowed the pairing of samples from burned and unburned patches at the same elevation and of the same aspect. Mature juniper trees were killed by the very intense fire that consumed the entire litter layer under the tree canopies and scorched the "A" horizon. Yucca-shrub patches appeared to have burned at a lower intensity than the juniper trees but with sufficient intensity to kill the shrubs and burn any litter layer present in the yucca-shrub patches. In less than one year after prescribed burns, it was not possible to clearly distinguish between the burned areas of the grassland matrix and the unburned areas with grass cover.

A total of 56 soil samples from the upper soil layers ( 0 - $10 \mathrm{~cm}$ ) were collected seasonally (early spring [March], late spring [May], summer [August] and autumn [October]) during 2009 and 2010. Soil samples were collected under juniper tree canopies (JBB, burned, and JNB, unburned patches) and in yucca-shrub patches (YBB, burned, and YNB, unburned patches) at the two watersheds that were prescribed-burned: one in 2006 and the other in 2008. The samples from the 2006 burned watershed provided data on soil nematode communities 3+ years after fire and the 2008 burned watershed provided data on soil nematode communities 1+ year post-burn. Sampling was a stratified random design.

Burned juniper patches suitable for sampling were identified by a dead tree trunk in the center of a circular patch of ash-colored soil. Burned yucca-shrub patches suitable for sampling were identified by charred Yucca baccata skeletons and charred stumps of shrubs. Burned yucca patches varied in size from approximately $1 \mathrm{~m}$ diameter to $3 \mathrm{~m}$ diameter. Unburned juniper and yucca soil samples were collected from unburned patches on the same alluvial piedmont slope with the same aspect. Soil samples were collected from burned juniper, burned yucca-shrub patches, unburned juniper, and unburned yucca-shrub patches at a site subjected to prescribed fire approximately one year prior to our study and at a site burned by prescribed fire three years prior to our study. 
Litter layers, if present, were removed prior to the collection of the soil sample. Five soil samples were collected from each type of patch-burned and unburned. Soils were sieved ( $2 \mathrm{~mm}$ mesh sieve) into ziplock plastic bags and placed in insulated coolers for transport to the laboratory.

The following analyses were performed on each soil sample: soil moisture was determined gravimetrically as a percentage of dry mass by drying the samples to a constant weight at $105^{\circ} \mathrm{C}$. Soil organic matter was measured by a modified method of Rowell [30]. Nematodes were extracted from $100 \mathrm{~g}$ fresh soil samples using the Baermann funnel procedure [31], and preserved in formaldehyde. The nematodes from each sample were identified to order, family, and genus using a compound microscope. Nematodes were classified into the following trophic groups according to known feeding habitats or stoma and esophageal morphology [32]: 1) bacteria feeders; 2) fungi feeders; 3) plant parasites; and 4) omnivore-predators. The total number of nematodes was counted and adjusted to $100 \mathrm{~g}$ dry soil.

The characteristics of the nematode communities were determined using the following indices: 1) absolute abundance of individuals adjusted to $100 \mathrm{~g}^{-1}$ dry soil (TN); 2) abundance of omnivore-predator (OP), plant-parasite $(\mathrm{PP})$, fungi-feeding (FF) and bacteria-feeding (BF) nematodes (trophic structure) [33]; 3) fungivore/bacterivore (FB) ratio, FB = FF/BF [34]; 4) trophic diversity ( $\mathrm{T}), \mathrm{T}=$ $1 / \sum \mathrm{Pi} 2$, where $\mathrm{Pi}$ is the proportion of the $\mathrm{i}$-th trophic group [35]; 5) Simpson's dominance index (D), Dom $=\sum \mathrm{Pi}^{2}[36]$; 6) Shannon-Weaver index (H'), $\mathrm{H}^{\prime}=-\sum \mathrm{p}_{\mathrm{i}}$ $\left(\ln \mathrm{p}_{\mathrm{i}}\right.$ ), where $\mathrm{P}$ is the proportion of individuals in the i-th taxon [37]; 7) maturity index (MI), MI= $\sum$ vífi/n, where ví, is the c-p value assigned by Bongers [38,39] of the i-th genus in the nematode, $\mathrm{fi}$ is the frequency of family $\mathrm{i}$ in the sample, and $\mathrm{n}$ is the total number of individuals in the sample [40]. The c-p values describe the nematode life strategies, and range from 1 (colonizers, tolerant of disturbance) to 5 (persisters, sensitive to disturbance); 8) modified maturity index (MMI), which includes plantfeeding nematodes [41]; 9) species richness, SR = $(\mathrm{S}-1) / \ln (\mathrm{N})$, where $\mathrm{S}$ is the number of taxa and $\mathrm{N}$ is the number of individuals identified [42].

\section{Statistical Analysis}

All data were subjected to statistical analysis of variance using the SAS model (GLM). Duncan's multiple range tests and Pearson correlation coefficient were used to evaluate differences between separate means (GLM, $[43,44])$. Differences with $p<0.05$ were considered statistically significant. In addition, the data were tested by computing redundancy discriminant analysis (RDA) in order to provide more information by taking into account the slope orientation. The sampling sites along the slopes were related to the different soil biotic components and the soil physical parameters in order to obtain the proportional variations that contribute to the understanding of each component [45]. The Monte Carlo permutation test was used to calculate the significance of a given factor and, thus, its relevance to the measured parameter [46].

\section{RESULTS}

Nematodes were more abundant in soils of burned and unburned juniper patches than in soils of burned and unburned yucca-shrub patches in most sampling periods. Soil organic-matter content was higher in the juniper patches than in the yucca patches on most sampling dates. There were no differences in soil organic matter between burned and unburned patches with the exception of the juniper samples in the autumn sampling period at the one year post-burn site (Table 1 ). Fire appeared to have the largest effect $(\mathrm{p}<0.05)$ on the soil nematode community during cool seasons, when there were large differences in soil moisture between the burned and unburned patches. In the early spring samples from both the one-year and three-year post-burn areas, soil nematodes were significantly more abundant in soils from unburned yuccashrub and juniper patches than from burned patches. While there were no differences in soil moisture between the burned and unburned yucca-shrub patches of the early spring samples, soil moisture was significantly higher in unburned juniper patches than in burned juniper patches (Table 1). The high amount of moisture in soils under unburned junipers in early spring resulted from the accumulation of soil water from the $165 \mathrm{~mm}$ of rainfall during the 5 months preceding the sample collection date. That rainfall was nearly three times higher than the longterm rainfall for that time period (data from the Jornada Experimental Range-rain gauge network).

Although moisture was higher in soils of unburned juniper patches than in soils of burned juniper patches in late spring, summer, and autumn, there were no differences in soil nematode abundance between late spring and summer. There were no differences in soil moisture of burned and unburned yucca-shrub patches between summer and autumn samples and no differences in soil nematode abundances between soils of yucca-shrub patches during these seasons. The late spring sampling was restricted to burned and unburned juniper patches in the one-year post-burn (2008) and three-year post-burn (2006) areas and there were no differences in soil nematode abundance between burned and unburned patches despite higher soil moisture in the unburned juniper patches in the one-year post-burn area (Table 1). Nematode abundance was significantly higher in unburned juniper patches than in burned juniper patches in the October samples but there were no differences in nematode abun- 
Table 1. Seasonal fluctuations in soil moisture (SM), organic matter (OM), average number of nematodes (TN), average numbers of bacteria-feeding nematodes (BF), fungi-feeding nematodes (FF), plant-parasitic nematodes (PP), and omnivore-predator nematodes (OP) \pm standard deviation.

\begin{tabular}{|c|c|c|c|c|c|c|c|c|c|}
\hline \multicolumn{10}{|c|}{ Numbers of nematodes and trophic groups in 100 grams of soil. } \\
\hline \multicolumn{10}{|l|}{ A, Juniper } \\
\hline $\begin{array}{c}\text { Time } \\
\text { sampling }\end{array}$ & $\begin{array}{l}\text { Year } \\
\text { of fire }\end{array}$ & Location & SM (\%) & $\mathrm{OM}(\%)$ & $\mathrm{TN}$ & $\mathrm{BF}$ & $\mathrm{FF}$ & $\mathrm{PP}$ & OP \\
\hline & 2006 & JBB & $11.65 \pm 2.43 b$ & $3.41 \pm 0.05 \mathrm{a}$ & $102.5 \pm 90.1 b$ & $54.8 \pm 51.0 \mathrm{~b}$ & $22.8 \pm 22.7 \mathrm{a}$ & $2.5 \pm 5.0 \mathrm{~b}$ & $22.0 \pm 16.6 b$ \\
\hline \multirow[t]{4}{*}{ Early Spring } & & JNB & $21.13 \pm 4.12 \mathrm{a}$ & $3.35 \pm 0.08 \mathrm{a}$ & $1314.8 \pm 349.3 a$ & $581.8 \pm 159.5 \mathrm{a}$ & $66.8 \pm 45.6 \mathrm{a}$ & $466.3 \pm 146.8 \mathrm{a}$ & $219.8 \pm 95.1 \mathrm{a}$ \\
\hline & 2008 & JBB & $7.68 \pm 3.34 b$ & $3.64 \pm 0.62 \mathrm{a}$ & $59.5 \pm 110.5 b$ & $85.5 \pm 111.0 \mathrm{~b}$ & $28 \pm 33.9 \mathrm{a}$ & 0 & $5.5 \pm 5.0 \mathrm{~b}$ \\
\hline & & JNB & $36.78 \pm 3.14 a$ & $3.54 \pm 0.01 \mathrm{a}$ & $3076.0 \pm 975.3 a$ & $1431.5 \pm 472.8 \mathrm{a}$ & $384.0 \pm 240.8 a$ & $943.8 \pm 569.1$ & $317.0 \pm 82.8 \mathrm{a}$ \\
\hline & 2006 & JBB & $3.60 \pm 0.35 a$ & $3.31 \pm 0.13 \mathrm{a}$ & $302.3 \pm 203.1 \mathrm{a}$ & $237.5 \pm 86.6 a$ & $64.5 \pm 117.7 \mathrm{a}$ & 0 & 0 \\
\hline \multirow[t]{4}{*}{ Late Spring } & & JNB & $4.73 \pm 0.98 \mathrm{a}$ & $3.32 \pm 0.12 \mathrm{a}$ & $221.3 \pm 119.2 \mathrm{a}$ & $141.3 \pm 126.3 a$ & $63.0 \pm 51.4 \mathrm{a}$ & $17.3 \pm 14.9$ & 0 \\
\hline & 2008 & JBB & $2.10 \pm 0.41 b$ & $2.85 \pm 0.69 \mathrm{a}$ & $275.5 \pm 278.5 a$ & $275.5 \pm 278.5 a$ & 0 & 0 & 0 \\
\hline & & JNB & $4.60 \pm 1.71 \mathrm{a}$ & $3.33 \pm 0.08 \mathrm{a}$ & $471.3 \pm 314.2 \mathrm{a}$ & $300.8 \pm 214.4 \mathrm{a}$ & $76.8 \pm 67.9$ & $31.5 \pm 33.8$ & $62.3 \pm 38.8$ \\
\hline & 2006 & JBB & $4.63 \pm 0.91 b$ & $1.61 \pm 0.04 a$ & $663.8 \pm 395.9 a$ & $569.5 \pm 453.2 \mathrm{a}$ & $17.5 \pm 17.2 \mathrm{a}$ & 0 & $76.3 \pm 99.1 \mathrm{a}$ \\
\hline \multirow[t]{4}{*}{ Summer } & & JNB & $8.78 \pm 0.84 a$ & $1.66 \pm 0.03 a$ & $452.8 \pm 258.9 a$ & $376.0 \pm 244.8 a$ & $32.3 \pm 45.1 \mathrm{a}$ & $25.5 \pm 10.7$ & $17.5 \pm 12.1 \mathrm{a}$ \\
\hline & 2008 & JBB & $4.88 \pm 0.51 b$ & $1.96 \pm 0.40 \mathrm{a}$ & $780.0 \pm 556.7 \mathrm{a}$ & $442.0 \pm 216.6 a$ & $159.5 \pm 165.2 \mathrm{a}$ & $24.5 \pm 42.6$ & $153.5 \pm 161.6$ \\
\hline & & JNB & $9.50 \pm 2.95 \mathrm{a}$ & $1.78 \pm 0.26 \mathrm{a}$ & $682.5 \pm 696.3 \mathrm{a}$ & $663.3 \pm 712.2 \mathrm{a}$ & $19.0 \pm 28.4 \mathrm{a}$ & 0 & 0 \\
\hline & 2006 & JBB & & & & & & & \\
\hline \multirow[t]{4}{*}{ Autumn } & & JNB & & & & & & & \\
\hline & 2008 & JBB & $2.78 \pm 0.71 b$ & $2.51 \pm 0.26 b$ & $31.8 \pm 7.2 \mathrm{~b}$ & $31.8 \pm 7.2 \mathrm{~b}$ & 0 & 0 & 0 \\
\hline & & JNB & $7.95 \pm 0.48 a$ & $3.10 \pm 0.20 \mathrm{a}$ & $484.3 \pm 193 a$ & $326.0 \pm 92.9 \mathrm{a}$ & $11.8 \pm 13.6$ & $35.8 \pm 26.3$ & $110.3 \pm 64.1$ \\
\hline & & Location $\mathrm{P}<$ & 0.0001 & 0.17 & 0.0001 & 0.0001 & 0.03 & 0.0001 & 0.0003 \\
\hline \multirow[t]{2}{*}{ Year } & & Year $\mathrm{P}<$ & 0.004 & 0.39 & 0.003 & 0.03 & 0.02 & 0.08 & 0.08 \\
\hline & & Seasons $P<$ & 0.0001 & 0.0001 & 0.0001 & 0.0003 & 0.02 & 0.0001 & 0.0001 \\
\hline \multicolumn{10}{|l|}{ B, Yucca } \\
\hline \multirow[t]{2}{*}{$\begin{array}{l}\text { Time sam- } \\
\text { pling }\end{array}$} & $\begin{array}{l}\text { Year } \\
\text { of fire }\end{array}$ & Location & SM (\%) & $\mathrm{OM}(\%)$ & $\mathrm{TN}$ & $\mathrm{BF}$ & $\mathrm{FF}$ & PP & $\mathrm{OP}$ \\
\hline & 2006 & YBB & $16.88 \pm 1.98 \mathrm{a}$ & $2.81 \pm 0.6 \mathrm{a}$ & $249.0 \pm 29.4 b$ & $139.8 \pm 19.4 b$ & $35.5 \pm 12.8 \mathrm{a}$ & $50.5 \pm 46.6 \mathrm{a}$ & $23.8 \pm 12.5 b$ \\
\hline \multirow[t]{4}{*}{ Early Spring } & & YNB & $18.90 \pm 0.78 a$ & $2.90 \pm 0.34 a$ & $931.5 \pm 252.2 \mathrm{a}$ & $484.3 \pm 117.7 \mathrm{a}$ & $44.8 \pm 32.0 \mathrm{a}$ & $122.8 \pm 67 a$ & $279.8 \pm 193.8 \mathrm{a}$ \\
\hline & 2008 & YBB & $12.55 \pm 2.31 \mathrm{a}$ & $2.69 \pm 0.43 a$ & $22.3 \pm 32.6 b$ & $13.3 \pm 16.5 b$ & $4.3 \pm 6.7 b$ & $1.3 \pm 2.5 b$ & $3.5 \pm 7.0 \mathrm{~b}$ \\
\hline & & YNB & $14.98 \pm 3.72 \mathrm{a}$ & $2.93 \pm 0.34 a$ & $1095.0 \pm 670.5 \mathrm{a}$ & $292.5 \pm 239.7 a$ & $205.0 \pm 95.8 \mathrm{a}$ & $228.5 \pm 182.7 \mathrm{a}$ & $368.8 \pm 210.0 a$ \\
\hline & 2006 & YBB & & & & & & & \\
\hline \multirow[t]{4}{*}{ Late Spring } & & YNB & & & & & & & \\
\hline & 2008 & YBB & & & & & & & \\
\hline & & YNB & & & & & & & \\
\hline & 2006 & YBB & $5.30 \pm 1.30 \mathrm{a}$ & $1.62 \pm 0.05 a$ & $312.8 \pm 230.2 \mathrm{a}$ & $219.3 \pm 176.7 a$ & $60.8 \pm 47.4 \mathrm{a}$ & $3.0 \pm 6.0 \mathrm{~b}$ & $28.3 \pm 34.6 \mathrm{a}$ \\
\hline \multirow[t]{4}{*}{ Summer } & & YNB & $6.30 \pm 1.94 a$ & $1.44 \pm 0.18 \mathrm{a}$ & $341.5 \pm 69 a$ & $125.3 \pm 107.3 a$ & $41.3 \pm 35.2 \mathrm{a}$ & $19.3 \pm 10.2 \mathrm{a}$ & $154.8 \pm 128.9 a$ \\
\hline & 2008 & YBB & $1.85 \pm 0.17 \mathrm{a}$ & $1.00 \pm 0.26 a$ & $384.3 \pm 291.8 \mathrm{a}$ & $218.5 \pm 249.9 a$ & $54.8 \pm 54.7 \mathrm{a}$ & $15.8 \pm 30.2$ & $94.5 \pm 143.2 \mathrm{a}$ \\
\hline & & YNB & $1.93 \pm 0.25 a$ & $1.08 \pm 0.04 a$ & $261.3 \pm 368.2 \mathrm{a}$ & $251.3 \pm 356.7 \mathrm{a}$ & $8.3 \pm 12.8 \mathrm{a}$ & 0 & $1.5 \pm 1.73 \mathrm{a}$ \\
\hline & 2006 & YBB & & & & & & & \\
\hline \multirow[t]{4}{*}{ Autumn } & & YNB & & & & & & & \\
\hline & 2008 & YBB & $2.53 \pm 0.40 \mathrm{a}$ & $2.0 .5 \pm 0.42 \mathrm{a}$ & $57.5 \pm 15.42 \mathrm{a}$ & $44.0 \pm 14.31 \mathrm{a}$ & $6.8 \pm 5.0 \mathrm{a}$ & 0 & $6.5 \pm 7.7 \mathrm{a}$ \\
\hline & & YNB & $2.60 \pm 0.69 \mathrm{a}$ & $2.01 \pm 0.22 \mathrm{a}$ & $74.0 \pm 9.42 \mathrm{a}$ & $47.0 \pm 6.98 \mathrm{a}$ & $3.0 \pm 3.8 \mathrm{a}$ & 0 & $23.8 \pm 15.5 a$ \\
\hline & & Location $\mathrm{P}<$ & 0.048 & 0.71 & 0.0007 & 0.049 & 0.04 & 0.006 & 0.0005 \\
\hline \multirow[t]{2}{*}{ Year } & & Year $\mathrm{P}<$ & 0.0001 & 0.03 & 0.86 & 0.44 & 0.13 & 0.59 & 0.9 \\
\hline & & Seasons $P<$ & 0.0001 & 0.0001 & 0.0008 & 0.05 & 0.003 & 0.0004 & 0.007 \\
\hline
\end{tabular}

JBB, Juniper burned area; JNB, Juniper unburned area. YBB, Yucca burned area; YNB, Yucca unburned area; *Different letters indicate significant differences between burnned and unburned sites of the same plants, $\mathrm{p}<0.05, \mathrm{n}=56$. 
dance between burned and unburned yucca-shrub patches.

Most of the differences in nematode abundance between burned and unburned patches were of bacteriafeeding nematodes. The average number of bacteriafeeding nematodes in soils of unburned juniper patches was an order of magnitude higher than in soils of burned juniper patches in the October samples. In the March samples, the numbers of bacteria-feeding nematodes in burned yucca-shrub and burned juniper patches were significantly lower than in soils of unburned yucca-shrub or juniper patches. There were no differences in bacteria feeders between soils of burned or unburned juniper or yucca-shrub patches in the late spring or summer samples (Table 1 ).

When all sampling dates were pooled together, all soil-nematode trophic groups were found to show a higher density value in soils under unburned junipers than in burned-juniper soil (Figure 1(a)). All trophic
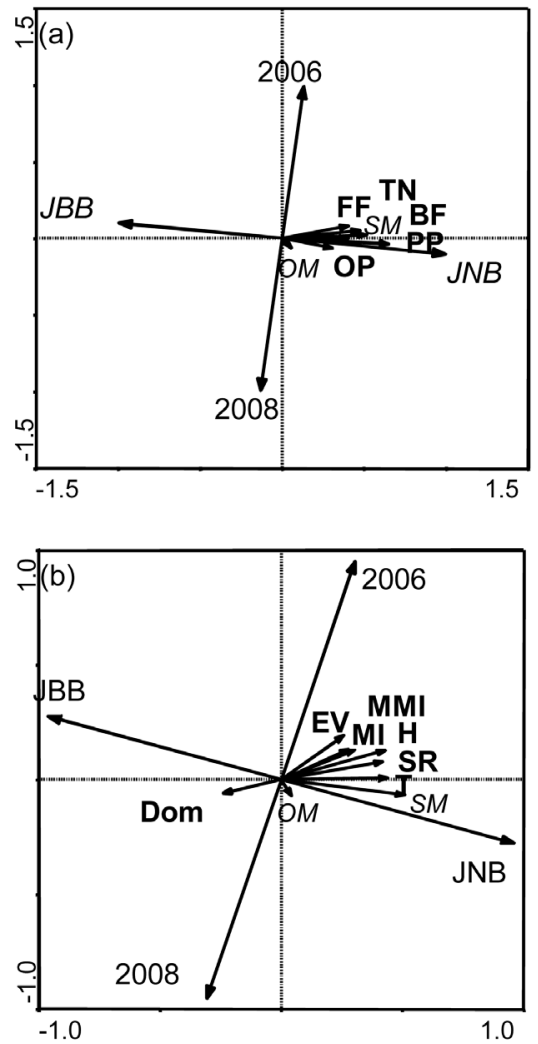

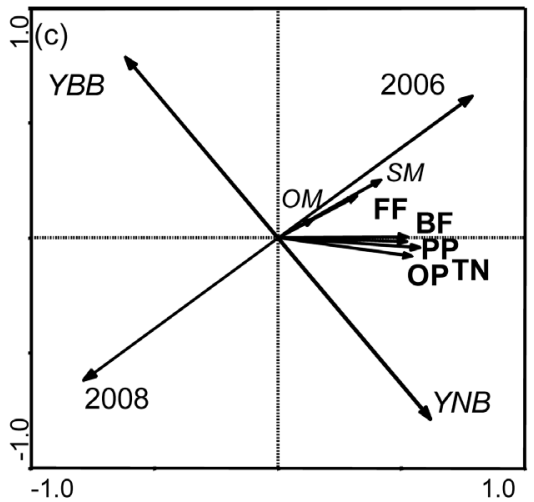

groups in the shrub soil patches were related to the higher soil moisture in the unburned yucca-shrub soils of the three-year post-burn site (Figure 1(c)). The ecological indices, with the exception of the dominance index, were higher in the unburned juniper soils of the three-year post-burn site than in the burned juniper soils of either site (Figure 1(b)). Most of the ecological indices were higher for the unburned yucca-shrub soils of the threeyear post-burn site with the exception of the maturity indices and the dominance index (Figure 1(d)).

Acrobeles was the most widespread genus among the bacterivores, followed by the genus Eucephalobus. These genera accounted for between 11.5 and $35.1 \%$ of the nematodes in the study area (Table 2). Aphelenchus and Tylencholaimus (except under juniper of the three-year post-burn patches) were the most abundant genera among the fungivores at the burned patches, while the abundance of Aphelenchoides was the highest among the fungivores from the unburned patches (Table 2).

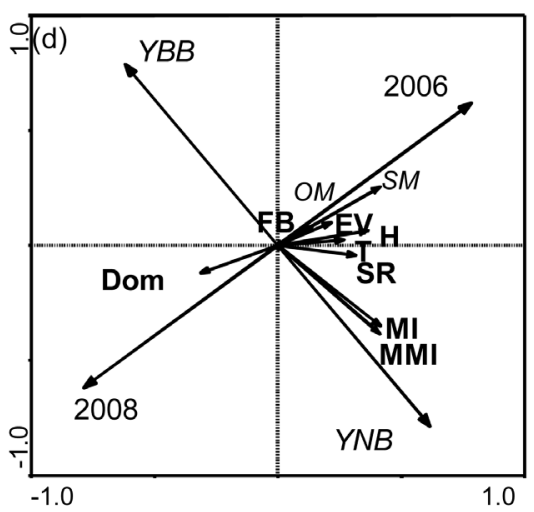

Figure 1. The soil free-living nematode community in soil samples collected under juniper trees (A, nematode communities, and B, ecological indices; JBB, burned, and JNB, unburned patches) and under Yucca shrubs (C, nematode communities, and D, ecological indices; YBB, burned, and YNB, unburned patches) compared in two years-2006 and 2008 (SM, soil moisture; OM, organic matter; TN, total number of nematodes; nematode trophic groups: BF, bacteria feeders; FF, fungi feeders; PP, plant parasites; OP, omnivorous-predators). Ecological indices of soil nematode communities in the observed soils: FB-fungivore-bacterivore ratio, $\mathrm{T}$ - trophic diversity, Dom-dominance index, $\mathrm{H}$ generic diversity index, MI—maturity index, MMI—-modified maturity index, EVevenness, SR species richness. 
Table 2. Mean abundance (\%) of soil free-living nematode genera at different burned and unburned sites in the vicinity of juniper and yucca.

\begin{tabular}{|c|c|c|c|c|c|c|c|c|}
\hline Year & $2006 y r$ & & $2008 y \mathrm{r}$ & & $2006 y \mathrm{r}$ & & 2008yr & \\
\hline Sampling site & JBB & JNB & JBB & JNB & YBB & YNB & YBB & YNB \\
\hline \multicolumn{9}{|l|}{ Trophic groups/ } \\
\hline \multicolumn{9}{|l|}{ genus/family } \\
\hline \multicolumn{9}{|l|}{ Bacterivores } \\
\hline Achromadora & 0 & 1.8 & 0 & 0 & 0.9 & 0 & 1.4 & 0 \\
\hline Acrobeloides & 6.8 & 1.7 & 4.8 & 2.5 & 4.9 & 7 & 0 & 1.4 \\
\hline Alaimus & 0 & 0 & 0 & 0.6 & 0 & 0 & 0 & 0 \\
\hline Cephalobus & 0.2 & 0 & 0.6 & 0 & 0 & 0 & 0 & 0.9 \\
\hline Cervidellus & 4.7 & 0.2 & 5.7 & 0.1 & 0.9 & 2.1 & 2.6 & 0 \\
\hline Chiloplacus & 6.4 & 1.5 & 1.6 & 0.6 & 18.5 & 5.6 & 9.1 & 0.6 \\
\hline Eumonhystera & 0.2 & 2.5 & 0 & 5.5 & 0 & 3.6 & 0 & 0.1 \\
\hline Heterocephalobus & 2.5 & 0 & 1.1 & 0 & 0 & 1 & 0 & 0.1 \\
\hline Leptolaimus & 0.4 & 1.2 & 7.3 & 0 & 0 & 2.1 & 0 & 0 \\
\hline Metateratocephalus & 0.2 & 0 & 0 & 4.6 & 0.6 & 0 & 0 & 0 \\
\hline Mesorhabditis & 0 & 0 & 0.3 & 0 & 0 & 0.6 & 0 & 0 \\
\hline Monhystera & 0.6 & 0.4 & 0 & 0.3 & 0 & 0 & 0 & 0 \\
\hline Panagrolaimus & 1.3 & 0.5 & 21.2 & 0.9 & 4.9 & 0 & 1.4 & 0.4 \\
\hline Plectus & 7.9 & 1.9 & 0 & 15.6 & 1.7 & 2.4 & 3.8 & 3.4 \\
\hline Prismatolaimus & 1.6 & 0.2 & 0.2 & 0.1 & 0.2 & 0.3 & 3.8 & 0.2 \\
\hline Rhabditis & 0 & 1.5 & 0 & 0.6 & 0 & 0 & 0 & 0 \\
\hline Teratocephalus & 2 & 0.2 & 0 & 0.2 & 0 & 0 & 2.9 & 0 \\
\hline Tylocephalus & 2.3 & 0.1 & 0.2 & 0 & 0 & 0 & 0 & 0 \\
\hline Fungivores & 0 & 0 & 0 & 0 & & 0 & 0 & 0 \\
\hline Aphelenchoides & 4.2 & 6.6 & 2.1 & 7.6 & 1.7 & 0.7 & 0.1 & 2.1 \\
\hline Aphelenchus & 5.2 & 0.1 & 0.6 & 0.9 & 12.7 & 2.6 & 5 & 4.2 \\
\hline Ditylenchus & 0.5 & 0.2 & 0 & 0.2 & 0 & 0 & 0 & 0 \\
\hline Leptonchus & 0 & 0 & 0 & 0 & 0 & 0 & 0 & 2.4 \\
\hline Nothotylenchus & 0 & 0 & 0 & 1.7 & 1.3 & 3.1 & 0 & 3.9 \\
\hline Tylencholaimus & 0 & 1.2 & 12.5 & 0.2 & 1.5 & 0.4 & 9 & 1.8 \\
\hline \multicolumn{9}{|l|}{ Plant-parasites } \\
\hline Aglenchus & 0 & 0 & 0 & 0 & 0 & 0 & 0 & 0.7 \\
\hline Basira & 0 & 0 & 0 & 0.1 & 0 & 2.6 & 0 & 0 \\
\hline Filenchus & 0 & 9.2 & 2.3 & 6.5 & 6.8 & 7.9 & 0.4 & 7 \\
\hline Helicotylenchus & 0 & 0.1 & 0 & 0 & 0 & 0 & 0 & 0 \\
\hline Hirschmanniella & 0.3 & 0.9 & 0 & 0 & 0 & 0 & 0 & 0 \\
\hline Heterodera & 0 & 3.3 & 0 & 0 & 1.6 & 0.6 & 0 & 0 \\
\hline Malenchus & 0 & 0 & 0 & 0 & 0 & 0 & 0.3 & 1.5 \\
\hline Longidorus & 0 & 0.6 & 0 & 0 & 0 & 0 & 0 & 0 \\
\hline Paralongidorus & 0 & 0 & 0 & 0.1 & 0 & 0 & 0 & 0 \\
\hline Psilenchus & 0 & 0 & 0 & 0 & 0 & 0 & 2.9 & 0 \\
\hline Pungentus & 0 & 0.8 & 0 & 0 & 0.6 & 0 & 0 & 0 \\
\hline Rotylenchus & 0 & 2 & 0 & 0 & 0 & 0 & 0 & 0 \\
\hline Trichodorus & 0 & 8.4 & 0 & 14.7 & 0 & 0 & 0 & 0 \\
\hline Tetylenchus & 0 & 0 & 0 & 0 & 0 & 0 & 0.2 & 0 \\
\hline
\end{tabular}




\begin{tabular}{|c|c|c|c|c|c|c|c|c|}
\hline Tylenchorhynchus & 0 & 0 & 0 & 0 & 0.6 & 0 & 0 & 7.4 \\
\hline \multicolumn{9}{|l|}{ Omnivores-predators } \\
\hline Aporcelaimus & 6 & 2.6 & 1.7 & 4.1 & 4.5 & 18 & 18.6 & 15.1 \\
\hline Aporcelaimellus & 1.6 & 0 & 0 & 4.4 & 0 & 7.7 & 1 & 8.2 \\
\hline Clarcus & 0 & 0.6 & 0 & 0.2 & 0 & 0 & 0 & 1.5 \\
\hline Discolaimus & 0 & 0 & 0 & 0.1 & 0 & 0 & 0 & 0 \\
\hline Eudorylaimus & 0 & 4.1 & 0 & 0.3 & 0 & 0 & 0 & 0 \\
\hline Dorylaimoides & 0 & 0.2 & 0 & 0.2 & 0 & 0 & 0 & 2 \\
\hline Epidorylaimus & 0 & 2.8 & 0 & 0 & 0 & 0 & 0 & 0 \\
\hline Microdorylaimus & 1.6 & 0.6 & 11.9 & 0 & 4.2 & 4.1 & 2.7 & 0.1 \\
\hline Mesodorylaimus & 0 & 0 & 0 & 0.3 & 0 & 0 & 0 & 0 \\
\hline Nygolaimus & 0 & 0.4 & 0 & 0 & 0.6 & 2.2 & 0 & 0.8 \\
\hline Oxydirus & 0 & 0.8 & 0 & 0 & 0 & 0 & 0 & 0 \\
\hline Paraxonchium & 0 & 0 & 0 & 0.6 & 0 & 2.3 & 0 & 0 \\
\hline Seinura & 0 & 0 & 0 & 0 & 0 & 0 & 0.4 & 0 \\
\hline
\end{tabular}

The genus Filenchus was the most dominant among the plant-parasite feeding groups in the burned patches (Table 2) while Trichodorus (under juniper) and Filenchus were the most dominant plant-parasite genera from soils of the unburned patches (Table 2). Aporcelaimus, followed by Microdorylaimus, was the most numerous among the omnivore-predator trophic groups in the burned patches, while Aporcelaimus, followed by the genus Aporcelaimellus, was the most dominant genus of the same trophic group in the unburned patches (Table 2).

\section{DISCUSSION}

The reported contradictory conclusions about the effects of fire on soil nematode communities are probably due to differences in fire intensities and the direct effect of the high temperatures on the soil biota [1]. While fire has been reported to change physical, chemical, and biological properties by heating and ash deposition [2], several months post-fire, differences in soil nematode communities were primarily attributable to the absence of shading and differences in rainfall redistribution rather than the direct effects of fire.

The direct effect of high temperatures on soil nematode communities is probably short-term whereas the long-term effects of fire depend on how fire intensity changes the structural features of the ecosystem. Koestner et al. [47] reported burn intensities measured by infrared thermometers during a prescribed fire in a savanna. In their study, burn temperatures of yucca-shrub patches ranged from $293^{\circ} \mathrm{C}$ to $620^{\circ} \mathrm{C}$ and the burn temperatures of junipers ranged from $587^{\circ} \mathrm{C}$ to $858^{\circ} \mathrm{C}$. They reported that the entire juniper litter layer was consumed by fire and that there was a gray-white residue on the mineral soil of the burned patches. While the differences in burn intensities may have affected the soil nematodes within days or weeks following the burn, studies initiated one or more years post-burn are more likely to provide information on the long-term effects of the structural changes in vegetation. Changes in ecosystem structure affect soil biota by modifying the thermal and hydrological characteristics of the soil.

One possible effect of high temperatures generated by fire is the combustion of organic matter in the upper soil layer. Prescribed fire in the juniper savanna ecosystems in this study did not affect the organic matter content of the mineral soil, possibly because of the more humus (compacted litter layer) structure of the soils. When the litter layer of the J. monosperma burned, there was little, if any, effect on the organic matter of the mineral soil because of the distinct boundary between the mineral soil and the litter layer. Since there were few differences in soil organic matter between burned and unburned patches, differences in the nematode communities of burned and unburned patches are not attributable to the effects of fire on soil organic matter.

In this study, the effects of fire on nematode communities were primarily due to the seasonal differences in soil moisture in burned vs. unburned patches. Seasonal differences in soil moisture resulted from increased soil temperature and higher evaporation rates due to direct exposure to solar radiation in burned patches compared to shaded unburned patches. These differences are what were predicted from previous studies and models of the dynamics of soil nematodes in arid regions that document the relationship between nematode abundance and diversity and seasonal rainfall and soil moisture [24-26]. Soils of unburned juniper patches were not exposed to direct sunlight because of the deep shade provided by the dense foliage of the canopies of Juniperus monosperma and the presence of an approximately 2-cm-deep litter layer under the tree canopies. In contrast, soils of unburned yucca-shrub patches were exposed to higher solar 
radiation because of the much sparser shade and a thin, variable-cover litter layer that did not provide complete shade of the mineral soil. Thus, the seasonal differences in the effects of fire on the nematode communities were the result of rainfall preceding the sampling and differences in evaporation rates of burned and unburned patches as a result of the loss of shade from the trees and shrubs.

The effects of fire on the soil and vegetation affected the species composition of the nematode communities by exerting different effects on the nematode genera. Jones et al. [48], following Yeates [49], expressed concerns that species-level discrimination of nematode taxa was necessary for their use as ecological indicators. They concluded that generalizations based on higher levels of taxonomy are speculative at best. While we could not discern the species, the abundance of bacteria-feeding nematodes Chiloplacus and Panagrolaimus was higher in the burned patches in comparison with the unburned ones and should be considered as indicators of the recovery trajectory following fire in this arid savanna ecosystem.

The bacteria-feeding nematodes, especially Eucephalobus spp., which exhibited the largest differences in abundance in burned and unburned patches, reflect the importance of soil moisture for the reproduction and growth of the bacteria upon which they feed. The effects of prescribed fires on the abundance of different trophic groups of nematodes reflect the relative dependence of the food required by the trophic groups on soil moisture. The fungi-feeding nematode genera, which were most abundant in the soils of burned patches, probably reflect the ability of the fungi on which they feed to grow in low-moisture conditions. In arid and semi-arid soils, the growth of fungal populations is much less dependent upon soil moisture than the growth of bacterial populations [50].

In conclusion, this study provides evidence that the long-term effects of fire in arid to semi-arid savannas on soil nematodes result from structural changes in the ecosystems: loss of microclimate-modifying tree and shrub canopies and loss of litter layers, which reduce rates of water loss from the mineral soil. Within a year after a fire, soil nematode abundance and community composition change with seasonal changes in soil water content and the soil microflora upon which they are dependent.

Over a long-term period (one to four years after fire), the effects of fire on soil nematode communities in an arid savanna ecosystem are primarily changes in the relative abundance of several dominant nematode genera. Differences in overall abundance and trophic composition are not obvious unless soil moisture is very different in burned and unburned patches.

The present study elucidates the importance of soil bi- ota in general and soil free-living nematodes in particular as bioindicators for determining resilience of natural ecosystems in time and space following the effects of fire.

\section{ACKNOWLEDGEMENTS}

This research would not have been possible without the assistance of the San Andres Wildlife Refuge personnel. We thank Mara Weisenberger of the San Andres Wildlife Refuge for suggesting accessible research sites and providing details of the prescribed fire program. Ms. Sharon Victor (Bar-Ilan University) assisted with the preparation of the manuscript. Funding for this study was from the International Arid Lands Consortium Grant No. 08R-06.

The authors hereby declare that there are no conflicts of interest associated with this manuscript.

\section{REFERENCES}

[1] Certini, G. (2005) Effects of fire on properties of forest soils: A review. Oecologia, 143, 1-10. http://dx.doi.org/10.1007/s00442-004-1788-8

[2] Doerr, S.H. and Cerda, A. (2005) Fire effects on soil system functioning: New insights and future challenges. International Journal of Wildland Fire, 14, 339-342.

[3] Michelsen, A., Andersson, M., Jensen, M., Kjoller, A. and Gashew, M. (2004) Carbon stocks, soil respiration and microbial biomass in fire-prone tropical grassland, woodland and forest ecosystems. Soil Biology and Biochemistry, 36, 1707-1717. http://dx.doi.org/10.1016/j.soilbio.2004.04.028

[4] Czimczik, C.I., Trumbore, S.E., Carbone, M.S. and Winston, G.C. (2006) Changing sources of soil respiration with time since fire in a boreal forest. Global Change Biology, 12, 957-971.

http://dx.doi.org/10.1111/j.1365-2486.2006.01107.x

[5] Gray, D.M. and Dighton, J. (2009) Nutrient utilization by pine seedlings and soil microbes in oligotrophic pine barrens forest soils subjected to prescribed fire treatment. Soil Biology and Biochemistry, 41, 1957-1965. http://dx.doi.org/10.1016/j.soilbio.2009.06.021

[6] Kara, O. and Bolat, I. (2009) Short-term effects of wildfire on microbial biomass and abundance in black pine plantation soils in Turkey. Ecological Indicators, 9, 11511155. http://dx.doi.org/10.1016/j.ecolind.2009.01.002

[7] Noble, J.C. (1997) The Delicate and Noxious Scrub: CSIRO Studies on Native Tree and Shrub Proliferation in the Semi-arid Woodlands of Eastern Australia. CSIRO Wildlife and Ecology, Lyneham, ACT.

[8] Valone, T.J., Nordell, S.E. and Ernest, S.K.M. (2002) Effects of fire and grazing on an arid grassland ecosystem. Southwestern Naturalist, 47, 557-565. http://dx.doi.org/10.2307/3672659

[9] Killgore, A., Jackson, E. and Whitford, W.G. (2009) Fire in Chihuahuan Desert grassland: Short-term effects on vegetation, small mammal populations, and faunal pedoturbation. Journal of Arid Environments, 73, 1029-1034. 
http://dx.doi.org/10.1016/j.jaridenv.2009.04.016

[10] Dick-Peddie, W.A. (1993) New Mexico Vegetation: Past, Present and Future. University of New Mexico Press, Albuquerque, NM.

[11] Weisberg, P.J., Ko, D., Py, C. and Bauer, J.M. (2008) Modeling fire and landform influences on the distribution of old-growth pinyon-juniper woodland. Landscape Ecology, 23, 931-943.

[12] Freckman, D.W. (1988) Bacterivorous nematodes and organic matter decomposition. Agriculture Ecosystems and Environment, 24, 195-217. http://dx.doi.org/10.1016/0167-8809(88)90066-7

[13] de Goede, R.G.M. and Bongers, T. (1994) Nematode community structure in relation to soil and vegetation characteristics. Applied Soil Ecology, 1, 29-44. http://dx.doi.org/10.1016/0929-1393(94)90021-3

[14] Bongers, T. and Ferris, H. (1999) Nematode community structure as a bioindicator in environmental monitoring. Trends in Ecology and Evolution, 14, 224-228. http://dx.doi.org/10.1016/S0169-5347(98)01583-3

[15] Yeates, G.W. (1982) Variation in pasture nematode populations over thirty-six months in a summer dry silt loam. Pedobiologia, 24, 329-346.

[16] Freckman, D.W. and Virginia, R.A. (1997) Low-diversity Antarctic soil nematode communities: Distribution and response to disturbance. Ecology, 78, 363-369.

http://dx.doi.org/10.1890/0012-9658(1997)078[0363:LD ASNC]2.0.CO;2

[17] Yeates, G.W., Wardle, D.A. and Watson, R.N. (1999) Responses of soil nematode populations, community structure, diversity and temporal variability to agricultural intensification over a seven-year period. Soil Biology and Biochemistry, 31, 1721-1733.

http://dx.doi.org/10.1016/S0038-0717(99)00091-7

[18] Neher, D.A. (2001) Role of nematodes in soil health and their use as indicators. Journal of Nematology, 33, 161168.

[19] Bloemers, G.F., Hodda, M., Lambshead, P.J.D., Lawton, J.H. and Wanless, F.R. (1997) The effects of forest disturbance on diversity of tropical soil nematodes. Oecologia, 111, 575-582. http://dx.doi.org/10.1007/s004420050274

[20] Yeates, G.W. and Lee, W.G. (1997) Burning in a New Zealand snow-tussock grassland: Effects on vegetation and soil fauna. New Zealand Journal of Ecology, 21, 7379.

[21] Fenster, M., Ferrick, C. and Scott, M. (2004) Fall burning does not affect nematode density or carbon and nitrogen levels in Iowa oak forest soils. Tillers, 5, 9-12.

[22] Matlack, G.R. (2001) Factors determining the distribution of soil nematodes in a commercial forest landscape. Forest Ecology and Management, 146, 129-143. http://dx.doi.org/10.1016/S0378-1127(00)00454-0

[23] McSorley, R. (1993) Short-term effects of fire on the nematode community in a pine forest. Pedobiologia, 37, 39-48.

[24] Steinberger, Y., Freckman, D.W., Parker, L.W. and Whitford, W.G. (1984) Effects of simulated rainfall and litter quantities on desert soil biota-Nematodes and microarthropods. Pedobiologia, 26, 267-274.

[25] Freckman, D.W., Whitford, W.G. and Steinberger, Y. (1987) Effect of irrigation on nematode population dynamics and activity in desert soils. Biology and Fertility of Soils, 3, 3-10.

[26] Moorhead, D.L., Freckman, D.W., Reynolds, J.F. and Whitford, W.G. (1987) A simulation-model of soil nematode population dynamics: Effects of moisture and temperature. Pedobiologia, 30, 361-372.

[27] Neary, D.G., Klopatek, C.C., DeBano, L.F. and Ffolliott, P.F. (1999) Fire effects on belowground sustainability: A review and synthesis. Forest Ecology and Management, 122, 51-71. http://dx.doi.org/10.1016/S0378-1127(99)00032-8

[28] Hart, S.C., DeLuca, T.H., Newman, G.S., MacKenzie, M.D. and Boyle, S.I. (2005) Post-fire vegetative dynamics as drivers of microbial community structure and function in forest soils. Forest Ecology and Management, 220, 166-184. http://dx.doi.org/10.1016/j.foreco.2005.08.012

[29] Pen-Mouratov, S., Hu, C., Hindin, E. and Steinberger, Y. (2011) Soil microbial activity and a free-living nematode community in the playa and in the sandy biological crust of the Negev Desert. Biology and Fertility of Soils, 47, 363-375. http://dx.doi.org/10.1007/s00374-011-0540-x

[30] Rowell, D.L. (1994) Soil Science: Methods and Applications. Longman Group UK Ltd., London.

[31] Cairns, E.J. (1960) Methods in nematology. In: Sasser, J.N. and Jenkins, W.R., Eds., Nematology, Fundamentals and Recent Advances with Emphasis on Plant Parasitic and Soil Forms, University of North Carolina Press, Chapel Hill, NC, 33-84.

[32] Yeates, G.W., Bongers, T., De Goede, R.G.M., Freckman, D. and Georgieva, S.S. (1993) Feeding habits in soil nematode families and genera-An outline for soil ecologists. Journal of Nematology, 25, 315-331.

[33] Steinberger, Y. and Loboda, I. (1991) Nematode population dynamics and trophic structure in a soil profile under the canopy of the desert shrub Zygophyllum dumosum. Pedobiologia, 35, 191-197.

[34] Twinn, D.C. (1974) Biology of Plant Litter Decomposition. Academic Press, London, New York.

[35] Heip, C., Herman, P.M.J. and Soetaert, K. (1988) Data processing, evaluation and analysis. In: Higgins, R.P. and Thiel, H., Eds., Introduction to the Study of Meiofauna. Smithsonian Institution Press, Washington DC, 197-231.

[36] Simpson, E.H. (1949) Measurement of diversity. Nature, 163, 668. http://dx.doi.org/10.1038/163688a0

[37] Shannon, C.E. and Weaver, W. (1949) The Mathematical Theory of Communication. University of Illinois Press, Urbana.

[38] Bongers, T. (1990) The maturity index: An ecological measure of environmental disturbance based on nematode species composition. Oecologia, 83, 14-19. http://dx.doi.org/10.1007/BF00324627

[39] Bongers, T. (1999) The Maturity Index, the evolution of nematode life history traits, adaptive radiation and cp- 
scaling. Plant and Soil 212, 13-22. http://dx.doi.org/10.1023/A:1004571900425

[40] Neher, D.A. and Darby, B.J. (2005) Computation and application of nematode community indices: General guidelines. In: Abebe, E., Ed., Freshwater Nematodes: Ecology and Taxonomy, CABI, Wallingford, 211-222.

[41] Yeates, G.W. (1994) Modification and qualification of the nematode maturity index. Pedobiologia, 38, 97-101.

[42] Yeates, G.W. and King, K.L. (1997) Soil nematodes as indicators of the effect of management on grasslands in the New England Tablelands (NSW): Comparison of native and improved grasslands. Pedobiologia, 41, 526-536.

[43] S.A.S. Institute (1988) SAS/ATAT User's Guide, Release 6.03, Cary.

[44] Sokal, R.R, and Rohlf, F.J. (1969) Biometry: Principles, Practices and Statistics in Biological Research. W.H. Freeman and Co., San Francisco.

[45] ter Braak, C.J.F. (1986) Canonical correspondence analysis: A new eigenvector technique for multivariate direct gradient analysis. Ecology, 67, 1167-1179. http://dx.doi.org/10.2307/1938672
[46] ter Braak, C.J.F. and Prentice, I.C. (1996) A theory of gradient analysis. In: ter Braak, C.J.F., Ed., Unimodal Models to Related Species Environment, DLO-Agricultural Mathematics Group, Wageningen, 138-271.

[47] Koestner, K.A., Neary, D.G., Gottfried, G.J. and Morales, R. (2008) Characteristics and behavior of a cool-season prescribed fire in the oak savannas of the southwestern borderlands. Hydrology and Water Resources in Arizona and the Southwest, 38, 41-46.

[48] Jones, K.L., Todd, T.C., Wall-Beam, J.L., Coolon, J.D., Blair, J.M. and Herman, M.A. (2006) Molecular approach for assessing responses of microbial-feeding nematodes to burning and chronic nitrogen enrichment in a native grassland. Molecular Ecology, 15, 2601-2609. http://dx.doi.org/10.1111/j.1365-294X.2006.02971.x

[49] Yeates, G.W. (2003) Nematodes as soil indicators: functional and biodiversity aspects. Biology and Fertility of Soils, 37, 199-210.

[50] Whitford, W.G. (1989) Abiotic controls on the functional structure of soil food webs. Biology and Fertility of Soils, 8, 1-6. http://dx.doi.org/10.1007/BF00260508 